\title{
Variation in Tomato spotted wilt virus Titer in Frankliniella occidentalis and Its Association with Frequency of Transmission
}

\author{
Dorith Rotenberg, Nallur K. Krishna Kumar, Diane E. Ullman, Mauricio Montero-Astúa, \\ David K. Willis, Thomas L. German, and Anna E. Whitfield
}

\begin{abstract}
First, fourth, and seventh authors: Department of Plant Pathology, Kansas State University, Manhattan 66506; second author: Indian Institute of Horticultural Research, Bangalore India 560089; third author: Department of Entomology, University of California, Davis 95616; fifth author: United States Department of Agriculture, Vegetable Crops Research Unit, Madison, WI 53706; and sixth author: Department of Entomology, University of Wisconsin, Madison 53706.
\end{abstract}

Accepted for publication 20 November 2008.

\begin{abstract}
Rotenberg, D., Kumar, N. K. K., Ullman, D. E., Montero-Astúa, M., Willis, D. K., German, T. L., and Whitfield, A. E. 2009. Variation in Tomato spotted wilt virus titer in Frankliniella occidentalis and its association with frequency of transmission. Phytopathology 99:404-410.

Tomato spotted wilt virus (TSWV) is transmitted in a persistent propagative manner by Frankliniella occidentalis, the western flower thrips. While it is well established that vector competence depends on TSWV acquisition by young larvae and virus replication within the insect, the biological factors associated with frequency of transmission have not been well characterized. We hypothesized that the number of transmission events by a single adult thrips is determined, in part, by the amount of virus harbored (titer) by the insect. Transmission time-course experi-

the experiments. On average, $59 \%$ of adults transmitted the virus during the first IAP ( 2 to 3 days post adult-eclosion). Male thrips were more efficient at transmitting TSWV multiple times compared with female thrips of the same cohort. However, females harbored two to three times more copies of TSWV-N RNA per insect, indicating that factors other than absolute virus titer in the insect contribute to a successful transmission event. Examination of virus titer in individual insects at the end of the third IAP (7 days post adult-eclosion) revealed significant and consistent positive associations between frequency of transmission and virus titer. Our data support the hypothesis that a viruliferous thrips is more likely to transmit multiple times if it harbors a high titer of virus. This quantitative relationship provides new insights into the biological parameters that may influence the spread of TSWV by thrips.
\end{abstract} ments were conducted using a leaf disk assay to determine the efficiency and frequency of TSWV transmission following 2-day inoculation access periods (IAPs). Virus titer in individual adult thrips was determined by real-time quantitative reverse transcriptase-PCR (qRT-PCR) at the end of
Additional keywords: Bunyaviridae, Thysanoptera, virus-vector interactions.
Tomato spotted wilt virus (TSWV) is the type member of the genus tospovirus, and it is considered one of the ten most devastating plant viruses (14). TSWV and its thrips vectors are widespread and cause extensive damage to numerous agronomic crops. Epidemics of TSWV and related tospoviruses cause serious to complete losses for growers of diverse food, fiber, and ornamental crops (7). For example, TSWV caused extensive damage to lettuce in Hawaii with crop losses of 50 to $90 \%$, crippling the vegetable industry (9). To date, there are few effective tools for controlling tospoviruses and thrips.

TSWV is an enveloped, negative-strand RNA virus. The virion measures 80 to $110 \mathrm{~nm}$ in diameter and is composed of an outer membrane envelope derived from the host. Two glycoproteins (GPs) are embedded in the membrane and project from the surface. The segmented genome is composed of three singlestranded RNAs, S (2.9 kb), M (4.8 kb), and L (8.9 kb), that are encapsidated in nucleocapsid protein $(\mathrm{N})$ and enclosed in the virion envelope $(10,11,21,23)$. All TSWV RNA segments are negative $(\mathrm{L})$ or ambisense ( $\mathrm{S}$ and $\mathrm{M})$, and proteins are expressed by translation of subgenomic RNA species. Of importance to this report, N RNA is transcribed from the $\mathrm{S}$ genome segment and has

Corresponding author: A. E. Whitfield; E-mail address: aewtospo@ksu.edu

doi:10.1094/PHYTO-99-4-0404

(c) 2009 The American Phytopathological Society been the target for polymerase chain reaction (PCR)-based detection of TSWV in plants $(12,26)$.

In nature, TSWV is transmitted from plant-to-plant almost exclusively by thrips $(1,39)$. Thrips belong to the insect order Thysanoptera and members of this order display an extraordinary amount of diversity with respect to food preference and behaviors. Frankliniella occidentalis (Pergande) is one of the most economically-important agronomic pests within this order because it is both a direct pest of crops and an efficient vector of tospoviruses. F. occidentalis is polyphagous, feeding on a wide array of plant species and plant organs. The insect is haplodiploid; unfertilized eggs develop into haploid males, while fertilized eggs develop into diploid females. The short reproductive cycle and high fecundity of this species contributes to its success as an invasive species. Because of its feeding and reproductive capacities, $F$. occidentalis is difficult to control effectively using the current strategies (25).

For circulative-propagative viruses like TSWV, vector competence is the inherent ability of the vector to acquire, circulate, replicate, and transmit a virus to a host (18). Several processes must occur for a thrips to be vector competent. First, virus acquisition must occur during the larval stages. Acquisition rates decrease as larval thrips develop (35), and pupal stages are nonfeeding and do not move. Adult thrips can transmit TSWV only if acquisition occurs during the larval stages (28). Adults that feed on infected plants do not transmit virus even if they are allowed 
lengthy feeding on tospovirus-infected plants (33). Second, the virus must bind to and infect the midgut epithelial cells, after which the virus replicates, spreads throughout the midgut, and subsequently infects the muscle cells surrounding the midgut and the primary salivary glands $(33,34)$. Presence of nonstructural proteins (NSs) and viral inclusions in the insect support the contention that TSWV replicates in the thrips vectors (34). Third, virus must enter and accumulate in the salivary glands of the adult thrips $(28,29)$. The extent of salivary gland infection has been shown to be a critical determinant of a successful transmission event $(22,29)$.

Real-time quantitative reverse transcriptase-PCR (qRT-PCR) is a sensitive, quantitative tool for measuring the relative and absolute abundance of host or pathogen RNA. The limits of detection for viruses in plant tissues have been shown to greatly exceed those of enzyme-linked immunosorbent assay (ELISA)based techniques $(20,24,27,31)$ and quantitative data obtained from these real-time experiments were highly reproducible. Boonham et al. (2) developed reliable RNA extraction and realtime qRT-PCR methods for detecting TSWV from single thrips. In a previous study, we used real-time qRT-PCR to quantify TSWV titer in individual adult thrips and found significant variation among viruliferous insects (38). In the present study, we explored the relationship between virus titer in adult thrips and transmission. Based on our understanding of vector competence, we hypothesized that the amount of TSWV harbored by adults of $F$. occidentalis is associated positively with transmission efficiency and the frequency of transmission (i.e., the number of transmission events by an individual thrips). Here, we report a robust positive relationship between virus titer and frequency of transmission to a plant host, for both male and female thrips. These data provide new insights into the factors that may influence the spread of TSWV by thrips.

\section{MATERIALS AND METHODS}

F. occidentalis and TSWV maintenance. A colony of the western flower thrips, $F$. occidentalis, was maintained on green bean pods (Phaseolus vulgaris) as previously described (33). To generate pools of first instar larvae (0- to 24-h old) for transmission experiments, clean beans were incubated with adult thrips for 3 days to allow oviposition, then adults were removed and beans were incubated at ambient room temperature $\left(23\right.$ to $\left.25^{\circ} \mathrm{C}\right)$ for $24 \mathrm{~h}$.

TSWV (isolate TSWV-MT2) was maintained by thrips transmission on Emilia sonchifolia L. as described previously (34). Two weeks prior to a transmission experiment, virus was mechanically transferred to Datura stramonium from young Emelia leaf tissue to increase virus titer in leaf tissues used for acquisition by larval thrips.

Transmission experiment design. Time-course experiments were conducted to determine transmission efficiency (proportion of transmitting adults in a cohort) and frequency (number of transmission events by an individual) over three consecutive, 2day inoculation access periods (IAPs). Based on preliminary experiments (data not shown), the 4th IAP ( 8 to 9 days post adulteclosion) marked a time of rapid decline in efficiency of transmission coupled with an increase in mortality. The first trial (experiment 1) included 134 females, and the second (experiment 2) and third (experiment 3 ) trials included equal numbers of females and males $(n=25$ each sex $)$.

Transmission assay. Experiments were conducted using a leaf disk assay (40) modified by Whitfield et al. (38). Pools of 24-h old first instars were given a 3 -h acquisition access period (AAP) on a bouquet of TSWV-infected $D$. stramonium leaves. The groups of larvae were moved to green beans and reared to adulthood. Twenty-four hours post adult-eclosion, individual thrips were transferred to $15-\mathrm{ml}$ conical polystyrene tubes (Falcon or
Sarsted) containing a 1-cm-square piece of Kimwipe to absorb excess moisture. A single 1.5-cm-diameter healthy D. stramonium leaf disk was placed near the middle of the tube, resting along the side. Insects were allowed a 48-h IAP, after which the leaf disk was replaced with a new disk to begin the next IAP. Leaf disks were incubated on the surface of water in microtiter plates for 4 days and TSWV detected by double-antibody sandwich enzyme-linked immunosorbent assay (DAS-ELISA) (Agdia). The proportion of leaf disks infected with TSWV was calculated, representing the proportion of transmitting adults during each IAP (efficiency). Individual insects were categorized into four transmission frequency classes: 0 to 3 , with $0=0 / 3,1=1 / 3,2=2 / 3$, and $3=3 / 3$ transmission events. Herein, we define one transmission event as the occurrence of virus transmission during a particular IAP, evidenced by a TSWV-positive leaf disk for that IAP. Six possible patterns of transmission were observed for classes 1 and 2: transmission during 1st, 2nd, or 3rd IAP only (class 1) and transmission during 1st and 2nd, 2nd and 3rd, or 1st and 3rd IAP (class 2). Immediately following the final IAP, thrips were placed in nuclease-free $1.5-\mathrm{ml}$ microcentrifuge tubes and stored at $-80^{\circ} \mathrm{C}$ for real-time PCR quantification of virus titer.

Estimation of TSWV titer in individual insects by normalized real-time quantitative reverse transcriptase-PCR (qRT-PCR). Total RNA was extracted from single thrips using the method of Boonham et al. (2). Briefly, $50 \mu$ of DEPC-treated water was delivered to the $1.5-\mathrm{ml}$ tubes containing the frozen thrips, and each was triturated with a disposable pellet pestle (Kontes). After homogenization, $50 \mu \mathrm{l}$ of a $50 \%$ slurry (wt/vol) of Chelex 100 (Bio-Rad) was added and samples were vortexed for $3 \mathrm{~s}$. Samples were heated at $94^{\circ} \mathrm{C}$ for $5 \mathrm{~min}$, centrifuged for $5 \mathrm{~min}$ at $13,000 \times g$ at $4^{\circ} \mathrm{C}$, and the supernatant was removed and used for cDNA synthesis. cDNA was made using the iScript cDNA synthesis kit (Bio-Rad), and $15 \mu \mathrm{l}$ of RNA was used for each $20 \mu \mathrm{l}$ reaction. Prior to amplification, the cDNA reaction was diluted up to $150 \mu \mathrm{l}$ with sterile deionized water to provide sufficient amounts of template for multiple reactions. Of this, $14 \mu \mathrm{l}$ of the cDNA sample served as the template for two technical replicates ( $7 \mu$ per reaction) for subsequent real-time PCR reactions.

Real-time qRT-PCR was performed on the TSWV nucleocapsid (N) gene (target) and thrips actin gene transcripts (internal reference) as previously described (38). The actin gene, a stably-expressed internal reference gene, provided a means of compensating for the sample to sample variation in RNA extraction and cDNA synthesis. The forward and reverse $\mathrm{N}$ primer sequences were 5'GCTTCCCACCCTTTGATTC3' and 5'ATAGCCAAGACAACACTGATC3', respectively. Because the TSWV-N primers amplify the N gene mRNA and TSWV S RNA, herein we refer to the template as TSWV-N RNA. The $F$. occidentalis actin primers described by Boonham et al. (2) were used for amplification of the actin gene (forward primer 5'GGTATCGTCCTGGACTCTGGTG3' and the reverse primer 5'GGGAAGGGCGTAACCTTCA3'). Both the TSWV-N RNA and actin primer pairs were tested for efficiency and specificity. We used iQ SYBR Green Mix (Bio-Rad) for all real time-PCR reactions according to manufacturer's specifications and $200 \mathrm{nM}$ of each primer. The iCycler iQ Thermal Cycler with $96 \times 0.2 \mathrm{ml}$ reaction module and iCycler iQ software (Bio-Rad) was used.

TSWV-N RNA (target) was normalized to actin expression (internal reference) to calculate the normalized abundance of TSWV-N RNA in each insect using the inverse equation in Pfaffl (30): $\mathrm{E}_{\text {actin }}{ }^{\mathrm{Ct}(\text { actin) }} / \mathrm{E}_{\mathrm{N}}{ }^{\mathrm{Ct}(\mathrm{N})}$; where $\mathrm{E}=\mathrm{PCR}$ efficiency of a primer pair (actin or $\mathrm{N}$ ), and $\mathrm{C}_{\mathrm{t}}=$ the amplification cycle number at which fluorescence emitted during the reaction first exceeds background fluorescence (i.e., threshold) and is inversely related to the initial template concentration in the PCR reaction. These $\mathrm{C}_{\mathrm{t}}$ values are automatically calculated by the IQ software. Efficiency values were calculated by $10^{(-1 / \text { slope })} ; \mathrm{E}=1.91$ and 1.93 were achieved for the $\mathrm{N}$ and actin primer pairs, respectively. The 
average normalized abundance ratios (representing the amount of virus (titer) harbored in TSWV-positive insects) were calculated for each transmission frequency class, for females and males separately.

Estimation of virus titer in female and male thrips by using an external TSWV-N standard. To estimate the number of molecules of TSWV-N RNA in female and male insects obtained from experiments 2 and 3, an external standard was prepared from a plasmid containing the TSWV-N gene (pBS-N2C4.5) (19). Purified plasmid DNA was quantified with the NanoDrop (Agilent) and linearized with BamHI. Use of linearized plasmids as external standards for real-time PCR applications have been shown to greatly enhance PCR efficiency and the amount of signal for the standard compared with supercoiled forms (8). As expected, digestion resulted in a single product of $4.5 \mathrm{~kb}$ in size (data not shown). The linearized plasmid was cleaned with the QIAquick PCR purification kit (Qiagen Sciences, MD) and quantified. A standard 10-fold dilution series, ranging from $3.15 \times$ $10^{6}$ copies to 3.15 copies per $\mu \mathrm{l}$ of PCR reaction, was prepared and $14 \mu \mathrm{l}$ of each dilution served as the template for two technical replicates. Using the same real-time PCR methods as described above, $14 \mu \mathrm{l}$ of the original cDNA sample was used.

The number of molecules of TSWV-N RNA per insect was estimated by calculating the average number of copies of target per reaction (two technical replicates) and multiplying this value by the dilution factor resulting from the RNA template (five-fold) and cDNA template dilutions (21.4-fold). The number of molecules per insect was $\log _{10}$-transformed prior to analysis. The average $\log _{10}$ (molecules of TSWV-N RNA) was calculated for each transmission frequency class for females and males separately.

Statistical analyses. Various nonparametric statistical analyses were performed. The three transmission experiments represented three independent biological replicates. The Kruskal-Wallis median test was performed with Minitab (MINITAB v.14, Minitab, Inc., State College, PA) to determine if (i) the efficiency of transmission (proportion of transmitting adults in a cohort) varied

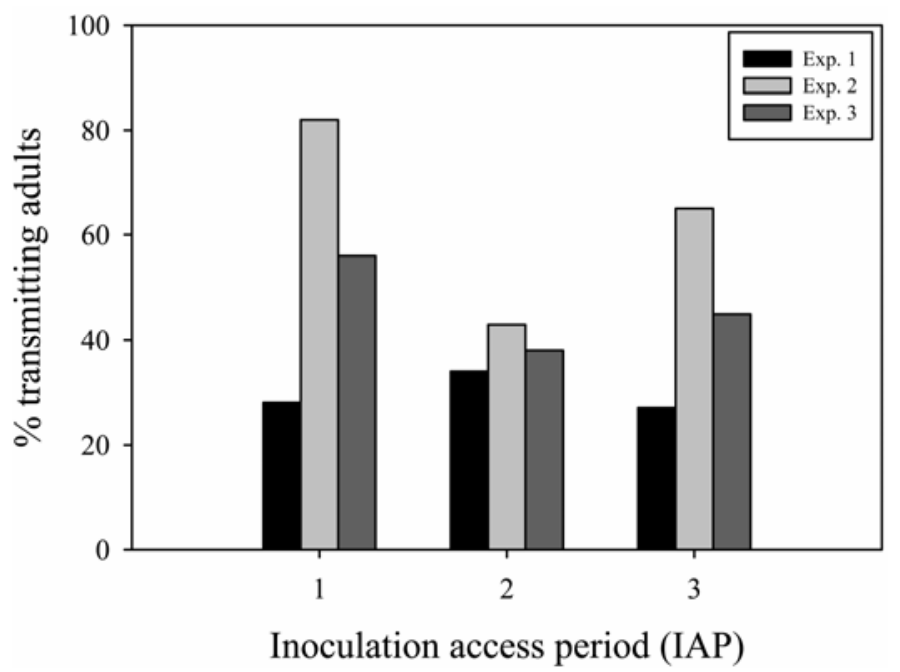

Fig. 1. Efficiency of Tomato spotted wilt virus (TSWV) transmission by Frankliniella occidentalis. Thrips were collected 0 to $24 \mathrm{~h}$ posteclosion from eggs and placed on a bouquet of TSWV-infected Datura stramonium leaves for acquisition access $(3 \mathrm{~h})$. Thrips were then reared to adulthood on bean pods and given 2-day inoculation access periods (IAPs) on D. stramonium leaf disks. For each insect, transmission was assayed three times after adult eclosion. Inoculation access periods were 2 to 3, 4 to 5, and 6 to 7 days after adult eclosion, respectively. Individual leaf disks were assayed for TSWV infection by double-antibody sandwich enzyme-linked immunosorbent assay to determine the proportion of transmitting adults. Experiment $1(\mathrm{n}=134)$ included female thrips only and experiments $2(\mathrm{n}=50)$ and $3(\mathrm{n}=50)$ included equal numbers of female and male thrips. There were no apparent differences among IAPs $(P=0.4)$ based on the Kruskal-Wallis median test. among IAPs and (ii) virus titer ( $\log _{10}$-transformed normalized abundance or $\log _{10}$ transformed number of molecules of TSWV-N RNA) varied among transmission frequency classes for each experiment. Pairwise comparisons were performed with the Mann-Whitney test statistic when an overall significance was found. The Fisher Exact probability test of independence was performed with SAS (SAS Institute Inc., Cary, NC) to determine if (i) transmission efficiency at each IAP was independent of sex and (ii) if the proportion of TSWV-infected males and females was independent of transmission frequency. The two-sided $P$ value was used to test the null hypothesis of independence. Spearman's rank correlation coefficients $\left(r_{s}\right)$ were calculated to determine the direction and magnitude of the associations between transmission frequency class and virus titer.

\section{RESULTS}

Efficiency of TSWV transmission. Adult thrips were tested for the ability to transmit TSWV over three IAPs in three independent transmission trials. On average, the efficiency of transmission during three consecutive IAPs was 59, 38, and 46\%, respectively (Fig. 1). In two of the three experiments, efficiency of transmission tended to be highest during the first IAP; however, there was no statistical difference $(P=0.4)$ among the IAPs. In the experiments that included both male and female thrips, the average efficiencies of transmission during the three consecutive IAPs for males were 70,51 , and $61 \%$ and for the females were 68,30 , and $48 \%$. While males tended to transmit TSWV more efficiently than females, there were no statistical differences between the sexes $(P>0.25)$ during the experimental time-frame.

Transmission frequency by sex. Based on the number of transmission events recorded for individual adults during each experiment, thrips were classified into four transmission classes (Table 1). On average across experiments, 24 and $40 \%$ of males and female thrips, respectively, did not transmit TSWV during the three consecutive IAPs (class 0). Within class 1 (transmission during 1 out of 3 IAPs), an average of $64 \%$ of females and $50 \%$ of males transmitted during the first IAP compared with $36 \%$ of females and $50 \%$ of males that transmitted during the 2 nd and $3 \mathrm{rd}$ IAP only. Within class 2 (2 out of 3 IAPs), an average of $34 \%$ of females and $29 \%$ of males transmitted during the first two IAPs

TABLE 1. Efficiency of Tomato spotted wilt virus (TSWV) transmission by male and female thrips of four transmission frequency classes

\begin{tabular}{lccc}
\hline Experiment & Sex & $\begin{array}{c}\text { Transmission } \\
\text { frequency class }^{\mathrm{z}}\end{array}$ & $\begin{array}{c}\text { Proportion of } \\
\text { insects }(\%)\end{array}$ \\
\hline 1 & Female & 0 & 57 \\
& $(\mathrm{n}=134)$ & 1 & 14 \\
2 & & 2 & 13 \\
& Female & 3 & 16 \\
& $(\mathrm{n}=25)$ & 0 & 16 \\
& & 1 & 12 \\
& & 2 & 48 \\
& Male & 3 & 24 \\
& $(\mathrm{n}=25)$ & 0 & 12 \\
& & 1 & 4 \\
& & 2 & 56 \\
& Female & 3 & 28 \\
& $(\mathrm{n}=25)$ & 0 & 44 \\
& & 1 & 20 \\
& & 2 & 16 \\
& Male & 3 & 20 \\
& $(\mathrm{n}=25)$ & 0 & 36 \\
& & 1 & 20 \\
& & 3 & 40 \\
\hline
\end{tabular}

${ }^{\mathrm{z}}$ Individual insects were categorized into four transmission frequency classes: 0 to 3 , with $0=0 / 3,1=1 / 3,2=2 / 3$, and $3=3 / 3$ transmission events. 
compared with $53 \%$ of females and $57 \%$ of males that transmitted during the 1 st and 3rd IAPs, skipping the 2nd IAP. There was no apparent association $(P>0.30)$ between pattern of transmission and virus titer in thrips (normalized abundance of TSWV-N RNA) within class 1 or class 2 .

A consistent pattern that emerged was that a greater proportion of males, on average, transmitted more frequently than females during the defined time-frame. Specifically, a larger proportion of males were more likely to transmit multiple times (classes 2 and 3) compared with females $(P=0.04)$. On average, 72 and $45 \%$ of the males and females, respectively, transmitted multiple times compared with 4 and $15 \%$ of the male and female insects that transmitted once.

Virus titer in adult thrips estimated by normalized abundance of TSWV-N RNA. Adult thrips were harvested from leaf disks at the end of each transmission experiment and the normalized abundance of TSWV-N RNA to thrips actin transcripts was determined. Real-time PCR of cDNA synthesized from total RNA extracted from individual male and female insects revealed that normalized abundance ratios of $\mathrm{N}$ to actin transcripts varied from 0.1 to 57.7 for female thrips and 0.7 to 236 for male thrips. The normalized abundance of $\mathrm{N}$ to actin transcripts per thrips was substantially higher in male versus females (Table 2). This apparent difference was due to the consistently higher $C_{t}$ values obtained for actin transcripts in males on a per insect basis $\left(\mathrm{C}_{\mathrm{t}}\right.$ male $=24 ; C_{t}$ female $=22$ ); therefore, comparisons of virus titer between the sexes could not be made based on the normalized abundance ratio. However, the consistent and reproducible $\mathrm{C}_{\mathrm{t}}$ values (low coefficient of variation $(\mathrm{CV})=1.8 \%$ to $5 \%$ ) for actin transcripts for each sex allowed us to compare virus titers within sex. The average normalized abundance of TSWV-N RNA in individual thrips was significantly greater in female and male insects $(P<0.0001)$ harvested from the experiment that produced the highest efficiency of transmission (experiment 2; Fig. 1).

Examination of normalized abundance ratios by transmission frequency class for both sexes revealed several reproducible patterns within and between frequency classes (Table 3). First, the degree of variation (coefficient of variation, CV) in normalized abundance ratios within each frequency class was high, regardless of sex. Second, despite this intra-class variation, the abundance of TSWV-N RNA in continuous transmitters (100\% frequency) was significantly higher $(P=0.008$ to 0.09$)$ compared with single transmitters of both sexes, with the exception of the females (Trial 2) that harbored significantly more TSWV-N RNA overall (Table 2 ). With the exception of these females, thrips with a normalized abundance ratio less than 2.5 were found only in the single-event and nontransmitter class. Third, the average normalized abundance ratio tended to be positively associated with number of transmission events (classes) for both male and female in four of the five comparisons.

To better understand the apparent difference in actin $C_{t}$ values between the sexes, it was necessary to determine if the difference

TABLE 2. Estimate of Tomato spotted wilt virus (TSWV) titer in adult thrips by real-time quantitative reverse transcriptase-polymerase chain reaction (qRT-PCR) of TSWV-N RNA normalized to thrips actin transcripts

\begin{tabular}{llccc}
\hline & & \multicolumn{2}{c}{ Avg. Ct value for } & \multirow{2}{*}{$\begin{array}{c}\text { Avg. normalized } \\
\text { abundance ratio }\end{array}$} \\
\cline { 3 - 4 } Experiment & Sex & TSWV-N & Thrips actin & \\
\hline 1 & Female & $18.9 \pm 3.2$ & $22.2 \pm 1.2$ & $7.3 \pm 9.2$ \\
2 & Female & $17.8 \pm 0.9$ & $22.1 \pm 0.4$ & $24.6 \pm 10.8$ \\
2 & Male & $18.9 \pm 2.9$ & $24.0 \pm 1.2$ & $60.3 \pm 48.6$ \\
3 & Female & $21.4 \pm 3.8$ & $21.9 \pm 0.6$ & $5.2 \pm 5.3$ \\
3 & Male & $21.7 \pm 1.8$ & $24.1 \pm 0.9$ & $11.5 \pm 12.4$ \\
\hline
\end{tabular}

${ }^{\mathrm{z}}$ Virus titer estimated by normalized abundance (ratio) of TSWV-N RNA to thrips actin transcripts calculated by the Pfaffl (30) equation: normalized abundance $=\mathrm{E}^{\mathrm{Ct}(\mathrm{actin})} / \mathrm{E}^{\mathrm{Ct}(\mathrm{N})}$, where $\mathrm{E}=$ efficiency of PCR for each primer pair. Averages (Avg.) include TSWV-positive insects only (no virus-free insects). was due to (i) significantly different amounts of total RNA per male and female insect, and therefore differences in actin cDNA template concentrations in the PCR reactions or, (ii) differentialexpression of actin in male versus female thrips. To quantify the abundance of total RNA in males versus females, total RNA was extracted from independent groups (20 or 100 insects) of nonexposed and TSWV-exposed male and female thrips. Females weighed 1.2 to 3 times more than males and contained 5 to 7 times more total RNA than males, regardless of virus infection. On a per insect basis, females and males weighed an average of 172 and $134 \mu \mathrm{g}$, respectively. On average, total RNA contents were $313 \mathrm{ng}$ and $54 \mathrm{ng}$ per female and male, respectively. Delivery of equal amounts of RNA (400 ng) to each cDNA reaction for each group of insects and subsequent real-time PCR revealed that there was no significant difference in actin $\mathrm{Ct}$ values $(P=0.2)$ obtained for male and female thrips $\left(\mathrm{C}_{\mathrm{t}}\right.$ males $=16.0 \pm$ 0.6 and $C_{t}$ females $\left.=16.6 \pm 0.4\right)$. This finding indicates that the difference in actin $C_{t}$ values between the individual female and male thrips harvested from the transmission experiments was due to the difference in total RNA delivered to the cDNA reaction.

Virus titer estimated by number of molecules of TSWV-N RNA in male and female thrips. As a means for comparing virus titers in males versus females obtained from the transmission experiments, an estimate of the number of molecules of TSWV-N transcripts per insect was determined by real-time PCR with an external standard. Real-time PCR of a dilution series of the standard was highly reproducible among five plates (independent runs) producing a CV ranging from $1 \%$ for the two most dilute standards to $3 \%$ for the two most concentrated standards. The PCR efficiency of the standard curve was, on average, $93 \%$ with an inter-plate $\mathrm{CV}$ of $1 \%$.

The average number of molecules of TSWV-N transcripts per insect differed between experiments (experiment 2 and experiment 3 ) and between females and males (Table 4). In line with our finding using the normalized abundance ratio to estimate titer, insects harvested from experiment 2 harbored 2.6 and 3.8 times

TABLE 3. Normalized abundance of Tomato spotted wilt virus (TSWV)-N RNA to thrips actin transcripts in female and male thrips that exhibited various frequencies of transmission

\begin{tabular}{|c|c|c|c|c|c|}
\hline \multirow[b]{2}{*}{ Experiment } & \multirow[b]{2}{*}{ Sex } & \multirow{2}{*}{$\begin{array}{l}\text { Transmission } \\
\text { frequency class }\end{array}$} & \multicolumn{3}{|c|}{ Normalized abundance ratio ${ }^{y}$} \\
\hline & & & Range & Mean & $\mathrm{CV}(\%)$ \\
\hline \multirow[t]{4}{*}{1} & Female & 0 & $0.1-15.2$ & $2.1 \mathrm{a}^{\mathrm{z}}$ & 165 \\
\hline & $(n=96)$ & 1 & $0.3-16.1$ & $5.7 \mathrm{~b}$ & 77 \\
\hline & & 2 & $2.5-57.7$ & $15.9 \mathrm{c}$ & 81 \\
\hline & & 3 & $2.7-30.7$ & $14.0 \mathrm{c}$ & 58 \\
\hline \multirow[t]{8}{*}{2} & Female & 0 & $\mathrm{n} / \mathrm{a}$ & $4.5^{*}$ & $\mathrm{n} / \mathrm{a}$ \\
\hline & $(\mathrm{n}=21)$ & 1 & $14.7-34.1$ & $24.4 \mathrm{a}$ & 56 \\
\hline & & 2 & $8.8-34.4$ & $22.5 \mathrm{a}$ & 37 \\
\hline & & 3 & $18.5-45.8$ & $32.1 \mathrm{a}$ & 33 \\
\hline & Male & 0 & $0.7-31.2$ & $15.9 \mathrm{a}$ & 136 \\
\hline & $(n=21)$ & 1 & $\mathrm{n} / \mathrm{a}$ & $63.1 *$ & $\mathrm{n} / \mathrm{a}$ \\
\hline & & 2 & $18.6-136.4$ & $48.1 \mathrm{a}$ & 62 \\
\hline & & 3 & $21.2-236.4$ & $90.8 \mathrm{a}$ & 77 \\
\hline \multirow[t]{8}{*}{3} & Female & 0 & $0.3-1.6$ & $1.1 \mathrm{a}$ & 49 \\
\hline & $(\mathrm{n}=19)$ & 1 & $0.8-7.0$ & $2.8 \mathrm{ab}$ & 85 \\
\hline & & 2 & $2.6-16.1$ & $7.4 \mathrm{bc}$ & 83 \\
\hline & & 3 & $4.0-18.9$ & $9.8 \mathrm{c}$ & 61 \\
\hline & Male & 0 & $0.2-9.3$ & $4.2 \mathrm{a}$ & 89 \\
\hline & $(n=23)$ & 1 & $\mathrm{n} / \mathrm{a}$ & $1.8^{*}$ & $\mathrm{n} / \mathrm{a}$ \\
\hline & & 2 & $3.5-21.2$ & $7.6 \mathrm{ab}$ & 102 \\
\hline & & 3 & $2.8-55.2$ & $16.2 \mathrm{~b}$ & 82 \\
\hline
\end{tabular}

${ }^{x}$ Individual insects were categorized into four transmission frequency classes: 0 to 3 , with $0=0 / 3,1=1 / 3,2=2 / 3$, and $3=3 / 3$ transmission events.

y Summary statistics include TSWV-positive insects only (no virus-free insects).

${ }^{\mathrm{z}}$ Pairwise comparisons between transmission frequency classes were performed using the Mann-Whitney test statistic; values followed by different letters signify sample distributions that are statistically significant at $P<$ 0.05 for each trial. * indicates $\mathrm{n}=1 ; \mathrm{n} / \mathrm{a}=$ not applicable. 
more $\mathrm{N}$ transcripts per female and male, respectively $(P=0.0001)$ than those collected from experiment 3 . Over both trials, virus titer ranged from $2.76 \times 10^{5}$ to $1.40 \times 10^{7}$ copies of $\mathrm{N}$ transcripts per female and $6.7 \times 10^{4}$ to $6.5 \times 10^{6}$ copies per male thrips. On average, females harbored 2 to 3 times more molecules of N RNA compared with males $(P<0.0001)$. There was no apparent difference $(P>0.25)$ in the copies of $\mathrm{N}$ transcripts per insect among the four transmission frequency classes. Nonetheless, the average number of $\mathrm{N}$ transcripts tended to be higher in female and male thrips that transmitted multiple times compared with only once.

Statistical correlations between virus titer and frequency of transmission. On a per insect basis, transmission frequency was significantly correlated to virus titer in both female and male thrips (Table 5). Estimation of virus titer as a normalized amount of TSWV-N RNA to thrips actin transcripts produced significant positive associations in all the three trials, regardless of sex. Similarly, significant associations between the number of molecules of TSWV-N RNA per insect and transmission frequency class were found in three of the four comparisons.

\section{DISCUSSION}

The extent of TSWV infection in adult thrips is a key determinant of vector competence. For example, Nagata et al. (29) found that a successful TSWV transmission event depended on extensive infection of both salivary gland lobes of adult thrips. In this study, we found that TSWV titer in individual adult thrips was a quantitative determinant of vector competence (to transmit or not to transmit), and moreover, virus titer was associated positively with the capacity of the viruliferous insect to transmit (frequency of events). With the use of real-time qRT-PCR to

TABLE 4. Estimation of $\log _{10}$ molecules of Tomato spotted wilt virus (TSWV)-N RNA per insect for thrips ${ }^{\mathrm{x}}$ that transmitted virus at various frequencies

\begin{tabular}{lcll}
\hline Experiment & Transmission frequency class $^{\mathrm{y}}$ & Females & Males \\
\hline 2 & 0 & 6.27 & 5.25 \\
1 & 6.55 & 6.10 \\
2 & 6.68 & 6.32 \\
3 & 6.66 & 6.38 \\
& Grand mean & $6.64 \mathrm{a}^{\mathrm{z}}$ & $6.23 \mathrm{~b}$ \\
3 & 5.28 & 5.03 \\
& 2 & 5.87 & 5.14 \\
& 3 & 6.26 & 5.53 \\
& Grand mean & 6.45 & 5.78 \\
& & $6.09 \mathrm{a}$ & $5.58 \mathrm{~b}$
\end{tabular}

${ }^{x}$ Data sets include TSWV-positive insects only (no virus-free insects).

y Individual insects were categorized into four transmission frequency classes: 0 to 3 , with $0=0 / 3,1=1 / 3,2=2 / 3$, and $3=3 / 3$ transmission events.

${ }^{\mathrm{z}}$ Significant differences $(P<0.01)$ between sexes within each transmission trial. quantify the abundance of TSWV-N RNA in adult insects and nonparametric statistics to analyze the variation in abundance, we revealed significant differences between infected/non-transmitting and infected/transmitting thrips, two biologically relevant types of thrips vectors documented previously $(35,37)$. At a finer resolution, we found quantitative differences in titer (normalized abundance of TSWV-N RNA) of viruliferous insects that transmitted once and those that transmitted continuously over three consecutive 2-day IAPs. Furthermore, statistical correlations indicated consistent and significant positive correlations between virus titer and frequency of transmission. Taken together, our results support a dose-dependent relationship between virus titer in adult thrips and the number of times a viruliferous thrips can transmit to a plant host.

Male and female thrips differed in their capacity to transmit TSWV. Viruliferous males were more likely to transmit multiple times than were females of the same cohort. This finding is supported by a study that documented a significantly greater proportion of $F$. occidentalis (NL3 isolate) males than females transmitting TSWV over three IAPs compared to one (37). In the present study, males contained significantly fewer copies of TSWV-N RNA within their bodies compared with females; therefore, it is likely that the higher efficiency of males to transmit more than once is due to differences in feeding behavior, and not necessarily titer. Generally, males are more mobile and probe plant tissue, rarely producing scarring (dead cells), while females are more sedentary, feeding at a particular site, resulting in the production of scars (36). van de Wetering et al. (36) found a negative association between scar formation and efficiency of transmission by female thrips. The authors proposed that less scarring results in virus being introduced into live tissue which supports virus replication compared with dead cells emptied of their contents. In the present study, we observed that females produced many dark green, single-point, and coalesced-areas of water-soaked lesions between leaf veins compared with males which produced areas of whitish discoloration on the leaf veins and significantly fewer water-soaked lesions (data not shown). Collectively, the damage caused by females covered a greater surface area of the leaf disk. The delivery of virus by the different feeding behaviors may be one explanation for the higher efficiency of males to transmit the virus in our study. An alternative hypothesis is that virus accumulates to a higher degree (more $\mathrm{N}$ ) in the salivary glands of males, even though the total pool of virus remains lower in male bodies compared with female bodies. To differentiate between these two possible scenarios, quantification of virus titer in thrips salivary glands specifically is needed.

Analysis of titer in male and female thrips revealed fundamental differences between the sexes. Expressing virus titer as the normalized abundance of TSWV-N RNA (target) to an endogenous standard (thrips actin RNA) revealed that, on a per unit RNA basis, males generally harbored more TSWV-N RNA rela-

TABLE 5. Significant correlations between transmission frequency and Tomato spotted wilt virus (TSWV) titer in individual thrips ${ }^{\mathrm{v}}$ estimated by normalized and absolute real-time quantivative reverse transcriptase-polymerase chain reaction (PCR)

\begin{tabular}{|c|c|c|c|c|c|}
\hline \multirow[b]{2}{*}{ Experiment } & \multirow[b]{2}{*}{ Sex } & \multicolumn{2}{|c|}{ Normalized abundance $^{\mathrm{w}}$} & \multicolumn{2}{|c|}{ Absolute abundance ${ }^{\mathrm{x}}$} \\
\hline & & $r_{s}{ }^{y}$ & $P$ value & $r_{s}{ }^{y}$ & $P$ value \\
\hline 1 & Female $(n=96)$ & 0.71 & $<0.0001$ & nd & nd \\
\hline 2 & Female $(\mathrm{n}=21)$ & 0.60 & 0.004 & 0.25 & 0.28 \\
\hline \multirow[t]{2}{*}{3} & Female $(\mathrm{n}=19)$ & 0.79 & $<0.0001$ & 0.78 & 0.0003 \\
\hline & Male $(\mathrm{n}=23)$ & 0.61 & 0.002 & 0.49 & 0.02 \\
\hline All & Both & 0.63 & $<0.0001$ & $0.51^{\mathrm{z}}$ & $<0.0001$ \\
\hline
\end{tabular}

${ }^{v}$ Data sets include TSWV-positive insects only as measured by real-time quantitative reverse transcriptase-PCR (qRT-PCR) of TSWV-N RNA.

${ }^{w}$ Virus titer estimated by $\log _{10}$-transformed normalized abundance (ratio) of TSWV-N RNA to thrips actin transcripts.

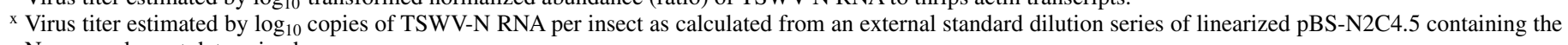
$\mathrm{N}$-gene. $\mathrm{nd}=$ not determined.

y Spearman's rank correlation coefficient $\left(\mathrm{r}_{\mathrm{s}}\right)$.

z Experiments 2 and 3 . 
tive to actin RNA compared with females (Table 2). We determined that this quantitative difference was largely due to the lower abundance of actin RNA in males compared with females. By definition, the endogenous reference RNA composes a relatively stable proportion of the RNA for any individual, and is therefore a good indicator of total RNA abundance. As such, differences in actin RNA abundance between males and females reflects differences in the total RNA per insect, which we determined to be the case by harvesting cohorts of female and male thrips. Thus, on a per unit RNA basis, viral RNA comprised a greater proportion of RNA extracted from male compared with female insects. This difference in normalized abundance is likely explained by the female tissues that are not susceptible to viral infection (i.e., eggs and reproductive tissues), but contribute to the RNA pool. Expressing virus titer as the copies of viral N RNA (cDNA) per insect, females harbored 2 to 3 times more molecules of N RNA per insect compared with males. In support of this finding, Sakurai et al. (32) documented on average, two times higher ELISA absorbance values (triple antibody sandwich [TAS]-ELISA) in individual TSWV-positive females compared with males of Japanese isolates of $F$. occidentalis. In this and the present study, the quantitative difference in titer between the sexes may be due, in part, to the difference in size/biomass of tissues that are susceptible to viral infection (midgut, salivary glands) in females versus males. Early reports inform us that female alimentary canals are 1.3 times longer and 1.4 times wider (average over length of gut) than male canals (data not shown).

The finding that the capacity of a thrips to transmit multiple times is associated with the amount of virus harbored by that insect has epidemiological implications. Our data indicate a dosedependent relationship between titer and number of transmission events. Based on our findings, we propose that quantification of TSWV titer in individual male and female thrips collected early in a growing season may prove to be one component of a model for predicting tomato spotted wilt disease incidence in the field. It has been shown that viruliferous adult thrips migrating from outside of a field are the primary source of TSWV inoculum early in the season (17). In peanut and tomato fields, evidence indicates that most infections during the season result from primary transmission by these TSWV-infected thrips $(6,13)$. In the present study, we found that the most transmission-efficient cohort of insects harbored the highest TSWV titer and that titer was correlated with frequency of transmission. It is possible that viruliferous thrips that harbor high titers of TSWV will be more likely to inoculate more plants in a particular stand, thus increasing the primary incidence of infection. Our findings warrant field studies to test this hypothesis empirically and to determine if virus titer in adult thrips can be a reliable indicator of TSWV incidence for a particular set of field conditions.

The use of real-time qRT-PCR as a tool to quantify and study the variation of TSWV titer in individual or groups of thrips may be applied more extensively to address various ecological questions. For example, the quantitative tool may be used to investigate inter- and intra-species variation of virus titer in other thrips species of economic importance, such as Frankliniella fusca and Thrips tabaci. Also, the technique could be used to study TSWV titer in natural populations of larval thrips on various acquisition hosts that serve as reservoirs of the virus, such as native perennials and weeds (16), or various agronomic plant genotypes that may support different viral titers or influence the variation in the amount of virus acquired by larval thrips.

The biotic and abiotic factors that influence the variation in TSWV titer in adult thrips have not been well characterized. It is not known why one individual of a cohort exposed to similar environmental conditions harbors a different titer compared with another individual from that same cohort. Genetic elements of both the virus and the vector ultimately determine if a particular species of vector and an individual within a species is able to vector a particular virus isolate (15). The variation in titer in a population of thrips may have a genetic basis. Cabrera-La Rosa and Kennedy (5) found that vector competence (i.e., efficiency of transmission) of $T$. tabaci to transmit TSWV is a heritable trait. Vector competence has been shown to be a complex, multigenic trait for two circulative, nonpropagative plant viruses vectored by aphids (4) and a circulative, propagative human virus vectored by mosquito (Aedes aegypti) (3). Work is underway in our laboratory to determine the vectoral and viral factors that influence TSWV titer in thrips.

\section{ACKNOWLEDGMENTS}

We thank J. A. Pierzynski for technical assistance. This research is supported by the National Research Initiative of the USDA Cooperative State Research, Education, and Extension Service, grant number 200701522. This manuscript is Kansas Agricultural Experiment Station contribution number 09-088-J.

\section{LITERATURE CITED}

1. Best, R. J. 1968. Tomato spotted wilt virus. Pages 65-145 in: Advances in Virus Research. K. M. Smith and M. A. Lauffer, eds. Academic Press, New York.

2. Boonham, N., Smith, P., Walsh, K., Tame, J., Morris, J., Spence, N., Bennison, J., and Barker, I. 2002. Detection of tomato spotted wilt virus (TSWV) in individual thrips using real time fluorescent RT-PCR (Taqman). J. Virol. Methods 101:37-48.

3. Bosio, C. F., Fulton, R. E., Salasek, M. L., Beaty, B. J., and Black, W. C. 2000. Quantitative trait loci that control vector competence for Dengue-2 virus in the mosquito Aedes aegypti. Genetics 1562:687-698.

4. Burrows, M. E., Caillaud, M. C., Smith, D. M., Benson, E. C., Gildow, F. E., and Gray, S. M. 2006. Genetic regulation of polerovirus and luteovirus transmission in the aphid Schizaphis graminum. Phytopathology 96:828837.

5. Cabrera La-Rosa, J. C., and Kennedy, G. G. 2007. Thrips tabaci and tomato spotted wilt virus: Inheritance of vector competence. Entomol. Exp. Appl. 124:161-166.

6. Camann, M. A., Culbreath, A. K., Pickering, J., Todd, J. W., and Demski, J. W. 1995. Spatial and temporal patterns of spotted wilt epidemics in peanut. Phytopathology 85:879-885.

7. Campbell, L. R., Robb, K. L., and Ullman, D. E. 2009. The complete Tospovirus host list. Provided online at http://www.oznet.ksu. edu.er.lib.ksu.edu/.

8. Chen, J., Kadlubar, F. F., and Chen, J. Z. 2007. DNA supercoiling suppresses real-time PCR: A new approach to the quantification of mitochondrial DNA damage and repair. Nucleic Acids Res. 35:13771388.

9. Cho, J. J., Mitchell, W. C., Mau, R. F. L., and Sakimura, K. 1987. Epidemiology of tomato spotted wilt virus disease on crisp lettuce in Hawaii. Plant Dis. 71:505-508.

10. de Haan, P., Kormelink, R., de Oliveira Resende, R., van Poelwijk, F., Peters, D., and Goldbach, R. 1991. Tomato spotted wilt virus L RNA encodes a putative RNA polymerase. J. Gen. Virol. 72:2207-2216.

11. de Haan, P., Wagemakers, L., Peters, D., and Goldbach, R. 1990. The S RNA segment of tomato spotted wilt virus has an ambisense character. J. Gen. Virol. 71:1001-1007.

12. Dewey, R. A., Semorile, L. C., and Grau, O. 1996. Detection of Tospovirus species by RT-PCR of the N-gene and restriction enzyme digestions of the products. J. Virol. Methods 56:19-26.

13. Gitaitis, R. D., Dowler, C. C., and Chalfant, R. B. 1998. Epidemiology of tomato spotted wilt in pepper and tomato in southern Georgia. Plant Dis. 82:752-756.

14. Goldbach, R. W., and Peters, D. 1994. Possible causes of the emergence of tospovirus diseases. Sem. Virol. 5:113-120.

15. Gray, S. M., and Banerjee, N. 1999. Mechanisms of arthropod transmission of plant and animal viruses. Microbiol. Mol. Biol. R. 63:128-148.

16. Groves, R. L., Walgenbach, J. F., Moyer, J. F., and Kennedy, G. G. 2002. The role of weed hosts and tobacco thrips, Frankliniella fusca, in the epidemiology of Tomato spotted wilt virus. Plant Dis. 86:573-582.

17. Groves, R. L., Walgenbach, J. F., Moyer, J. W., and Kennedy, G. G. 2003. Seasonal dispersal patterns of Frankliniella fusca (Thysanoptera: Thripidae) and tomato spotted wilt virus occurrence in Central and Eastern North Carolina. J. Econ. Entomol. 96 1:1-11.

18. Hardy, J. L., Houk, E. J., Kramer, L. D., and Reeves, W. C. 1983. Intrinsic factors affecting vector competence of mosquitoes for Arboviruses. Annu. 
Rev. Entomol. 28:229-262.

19. Kim, J. W., Sun, S. S. M., and German, T. L. 1994. Disease resistance in tobacco and tomato plants transformed with the tomato spotted wilt virus nucleocapsid gene. Phytopathology 78:615-621.

20. Korimbocus, J., Coates, D., Barker, I., and Boonham, N. 2002. Improved detection of Sugarcane yellow leaf virus using a real-time fluorescent (TaqMan) RT-PCR assay. J. Virol. Methods 103:109-120.

21. Kormelink, R., de Haan, P., Meurs, C., Peters, D., and Goldbach, R. 1992. The nucleotide sequence of the M RNA segment of tomato spotted wilt virus, a bunyavirus with two ambisense RNA segments [published erratum appears in J. Gen. Virol. 1993. 74:790]. J. Gen. Virol. 73:27952804.

22. Kritzman, A., Gera, A., Raccah, B., van Lent, J. W. M., and Peters, D. 2002. The route of tomato spotted wilt virus inside the thrips body in relation to transmission efficiency. Arch. Virol. 147:2143-2156.

23. Law, M. D., Speck, J., and Moyer, J. W. 1992. The M RNA of impatiens necrotic spot tospovirus (Bunyaviridae) has an ambisense genomic organization. Virology 188:732-741.

24. Mason, G., Caciagli, P., Accotto, G. P., and Noris, E. 2008. Real-time PCR for the quantitation of Tomato yellow leaf curl Sardinia virus in tomato plants and in Bemisia tabaci. J. Virol. Methods 147:282-289.

25. Morse, J. G., and Hoddle, M. S. 2006. Invasion biology of thrips. Annu. Rev. Entomol. 51:67-89.

26. Mumford, R. A., Barker, I., and Wood, K. R. 1996. An improved method for the detection of Tospoviruses using the polymerase chain reaction. J. Virol. Methods 57:109-115.

27. Mumford, R., Skelton, A., Metcalfe, E., Walsh, K., and Boonham, N. 2004. The reliable detection of Barley yellow and mild mosaic viruses using real-time PCR (TaqMan). J. Virol. Methods 117:153-159.

28. Nagata, T., Inoue-Nagata, A. K., Smid, H. M., Goldbach, R., and Peters, D. 1999. Tissue tropism related to vector competence of Frankliniella occidentalis for Tomato spotted wilt tospovirus. J. Gen. Virol. 80:507-515.

29. Nagata, T., Inoue-Nagata, A. K., van Lent, J., Goldbach, R., and Peters, D. 2002. Factors determining vector competence and specificity for transmission of Tomato spotted wilt virus. J. Gen. Virol. 83:663-671.

30. Pfaffl, M. W. 2001. A new mathematical model for relative quantification in real-time RT-PCR. Nucleic Acids Res. 29:e45.
31. Ratti, C., Budge, G., Ward, L., Clover, G., Rubies-Autonell, C., and Henry, C. 2004. Detection and relative quantitation of Soil-borne cereal mosaic virus (SBCMV) and Polymyxa graminis in winter wheat using real-time PCR (TaqMan). J. Virol. Methods 122:95-103.

32. Sakurai, T., Murai, T., Maeda, T., and Tsumuki, H. 1998. Sexual differences in transmission and accumulation of tomato spotted wilt virus in its insect vector Frankliniella occidentalis (Thysanoptera: Thripidae). Appl. Entomol. Zool. 33:583-588.

33. Ullman, D. E., Cho, J. J., Mau, R. F. L., Wescot, D. M., and Custer, D. M. 1992. A midgut barrier to tomato spotted wilt virus acquisition by adult western flower thrips. Phytopathology 82:1333-1342.

34. Ullman, D. E., German, T. L., Sherwood, J. L., Wescot, D. M., and Cantone, F. A. 1993. Tospovirus replication in insect vector cells: Immunocytochemical evidence that the nonstructural protein encoded by the S RNA of tomato spotted wilt tospovirus is present in thrips vector cells. Phytopathology 83:456-463.

35. van de Wetering, F., Goldbach, R., and Peters, D. 1996. Tomato spotted wilt tospovirus ingestion by first instar larvae of Frankliniella occidentalis is a prerequisite for transmission. Phytopathology 86:900-905.

36. van de Wetering, F., Hulshof, J., Posthuma, K., Harrewijn, P., Goldbach, R., and Peters, D. 1998. Distinct feeding behavior between sexes of Frankliniella occidentalis results in higher scar production and lower tospovirus transmission by females. Entomol. Exp. Appl. 88:9-15.

37. van de Wetering, F., van der Hoek, M., Goldbach, R., and Peters, D. 1999. Differences in tomato spotted wilt virus vector competency between males and females of Frankliniella occidentalis. Entomol. Exp. Appl. 93:105-112.

38. Whitfield, A. E., Kumar, N. K. K., Rotenberg, D., Ullman, D. E., Wyman, E. A., Zietlow, C., Willis, D. K., and German, T. L. 2008. A soluble form of the Tomato spotted wilt virus (TSWV) glycoprotein $\mathrm{G}_{\mathrm{N}}\left(\mathrm{G}_{\mathrm{N}}-\mathrm{S}\right)$ inhibits transmission of TSWV by Frankliniella occidentalis. Phytopathology 98:45-50.

39. Whitfield, A. E., Ullman, D. E., and German, T. L. 2005. TospovirusThrips Interactions. Annu. Rev. Phytopathol. 43:459-489.

40. Wijkamp, I., and Peters, D. 1993. Determination of the median latent period of two tospoviruses in Frankliniella occidentalis, using a novel leaf disk assay. Phytopathology 83:986-991. 